\title{
Isolation and Identification of Fungi Inhabiting Rubber- impregnated Wood, and Their Role of Quality Changing the Impregnated Wood
}

Noor Rahmawati, Ihak Sumardi,* and Rudi Dungani

Knowledge of the types of fungi inhabiting wood, their growth conditions, and level of damage is needed to design an effective and efficient preservation process. Researchers have tried to identify fungi that play a role in attacking wood products (impregnated wood), including the type and the role of these fungi in changing the quality of processed wood. Isolation was completed on fungal-attacked wood. The first isolation resulted in approximately 26 isolates, which were then grouped into 8 groups based on the macroscopic appearance of the fungus. Molecular identification of the fungi produced types of Aspergillus tamarii, Penicillium citrinum, Trichoderma longibrachiatum, Trichoderma reesei, and Fusarium solani. Chemical analysis using the Chasson Datta method was performed on attacked and non-attacked wood. A decrease was found in cellulose content and an increase in lignin content for impregnated wood attacked by fungi. It was suspected that there were cellulose-attacking fungi that consumed cellulose, which caused a decrease in cellulose content. An increasing lignin content was thought to be caused by phenols, produced by the delignification process by fungi and additional phenols from the impregnation process. Fourier transform infrared results revealed the presence of carbohydrates, showing that the degradation of cellulose by fungi produced simple carbohydrates.

Keywords: Decay wood; FTIR; Identification; Impregnated wood

Contac information: School Life Sciences and Technology-Bandung Institute of Technology, Jalan Ganesha 10 Bandung, Indonesia; *Coresponden author: ihak@sith.itb.ac.id

\section{INTRODUCTION}

Wood is a renewable natural resource and is used extensively throughout the world as a raw material for construction. However, wood is classified as biodegradable (biologically degraded) and is often influenced by biotic and abiotic agents that can cause it to decay over time. Biotic factors that influence the strength of wood include fungi and wood-damaging insects, while abiotic factors consist of temperature, humidity, and water content. Continuous exposure of wood material in a supportive environment can result in a process of disintegration and deterioration of wood and degradation of each component (Gu 2003).

Wood is a natural organic material that is susceptible to the process of biodegradation and affected by insecticides, fungi, and bacteria (Kalawate and Mahetre 2015). There are various types of wood-inhabiting fungi (WIF), which include many classes of species such as mold, staining fungi, and decay fungi. These fungi can cause economic losses when using wood (Scheffer 1973). Wood that is exposed to the environment is vulnerable to damage and decay. Wood is effectively decomposed by 
microbial agents. In conditions above ground and in a non-watery environment wood is mainly degraded by basidiomycetes fungi.

Many methods are used to control wood degradation by WIF, such as watering, chemical preservation using preservatives, or drying the wood. The use of biological agents to protect wood is an alternative to the latest fungicides. Research on WIF that affect wood in storage is needed to efficiently control their growth in wood and processed wood using biological products. Protection of wood from fungi has always been a challenge. The use of a highly durable or pre-harvested wood species with suitable wood preservatives offers satisfactory protection, is cost effective, and lasts for a lengthy period of time (Kumar et al. 1995; Kalawate and Mehetre 2015).

Decaying wood and wood products are a serious and expensive problem for the forest product industry. Although the purpose of mold decay is to decompose fallen trees and dead wood in the forest, they also affect structural wood products.

Structural damage caused by wood rot has increased sharply; so research is needed on wood-destroying fungi that attack wood at various stages of wood processing. This is important, because different fungi will have different physiologies; the growth conditions that support them will also vary. The identification of these wood-destroying fungi is carried out via isolation and observation of growth characteristics in different culture media until the spore formation, including identification of the factors that can inhibit or accelerate the growth of fungi on wood. Key identification based on morphological characteristics by macroscopy, microscopy, and molecular in fungal culture is used to determine the fungi in question.

Thus, early detection and identification of wood staining and weathering fungi can result in proper wood care and processing to save time and money. The purpose of this study is to investigate the type of wood-destroying fungi and the level of damage at each stage of the wood processing process (logs, veneers to laminated veneer lumber, LVL). The long target of this research is to produce wood preservation techniques in each stage of the wood processing process based on a database of wood-destroying organisms (fungi) obtained in the previous research stage.

In this research, processed wood derived from rubber wood was chosen because those products were widely used by the community due to its bright appearance. Also, with such specimens the exposure to fungi and destructive fungi infection will be clearly seen. In addition, rubber wood contained a lot of starch, which made it susceptible to fungi, both dyes and decay.

The aim of this research was to isolate the wood-inhabiting fungi from impregnated rubber wood. The fungal isolates obtained from the product were identified on macroscopic and molecular levels, and characterization of the wood damage caused by fungi was also performed.

\section{EXPERIMENTAL}

\section{Materials}

The materials used in this study were impregnated wood specimens that either had been subject to fungal infection or without fungal infection. All impregnated wood was kept in air-dry conditions with a moisture content of 14 to $18 \%$. The impregnated wood used was laminated veneer lumber (LVL) which made from rubber wood veneer (Hevea brasiliensis) that had been impregnated with low molecular phenol formaldehyde resin 
(impregnant level of 20\%). Meanwhile, the chemicals used were potato dextrose agar (Merck, Darmstadt, Germany), nutrien agat (Oxoid, Basingstoke, England), nutrient broth (Oxoid, Basingstoke, England), sulfuric acid (H2SO4) (Merck, Darmstadt, Germany), ethyl acetetate (Merck, Darmstadt, Germany), methanol (Merck, Darmstadt, Germany), and DPPH radical (2,2-Di(4-tert-octylphenyl)-1-picrylhydrazy (Sigma Aldrich, St. Louis, MO, USA).

Preliminary surveys were conducted in 2019 to collect wood affected by fungi and insects from sawmills in PT SGS Tangerang, Indonesia. Ten examples of wood that had previously been placed outdoors were selected from impregnated wood that had experienced a severe attack of mold. In one panel, five fungal attack points were taken for isolation. Wood samples with severe damage (Fig. 1) were brought to the laboratory and the fungi in them were isolated.
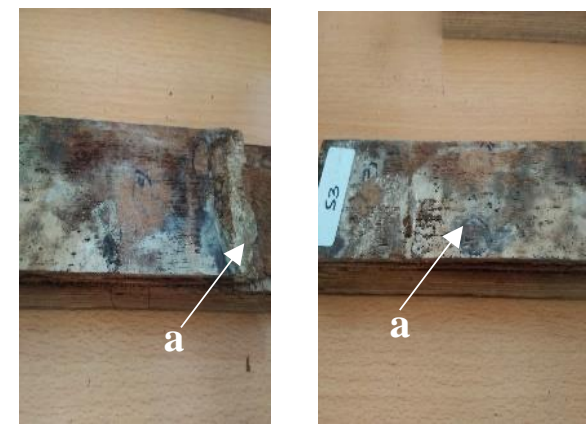

Fig. 1. Impregnated rubber wood samples studied (a) determination of spots for isolation of wood-destroying fungi based on damage or staining on laminated wood

Isolation of fungi was performed using the serial dilution technique. Twenty-six isolates of fungus were grown on potato dextrose agar (PDB, Sigma Aldrich, St. Louis, $\mathrm{MO}$, USA) by incubation at $30{ }^{\circ} \mathrm{C}$ for 4 to 5 days. The fungi were observed under a microscope (Nikon Eclipse E200 LED, Shinagawa-ku, Tokyo, Japan) for their colony characterization and hyphal structure.

\section{Isolation of Fungi that Infected Wood}

Molecular identification of the ITS rDNA gene was completed using the sequencing method. DNA samples used for sequencing must be pure and specific in the gene for species or strain determination. Thus, it is necessary to process the extraction of fungal DNA first, then do PCR to amplify the ITS1 / ITS4 region. To ensure the ampification process, electrophoresis was used afterwards.

The Genofic from the fungal specimens was extracted using a DNA Extraction Kit from Zymoresearch, Irvine, CA, USA. The extracted DNA was used as a template to amplify the 18 S R DNA gene via polymerase chain reaction (PCR, BioRad T100 thermal cycler; Biorad Laboratories, Singapore), with the forward primer internal transcribed spacer (ITS) (1) TCTGTAGGTGAACCTGCGG and reverse primer ITS (4) TCCTCCGCTTATTGATATGC. The PCR products were resolved by electrophoresis (Mupid Exu Electrophoresis System, Advance Japan). The sequencing PCR (BioRad T100 thermal cycler; Biorad Laboratories, Singapore) was set up with an ABI-Big Dyes Terminator v3.1 Cycle Sequencing Kit (Life Technologies Holdings Pte Ltd., Singapore) in accordance with manufacturer's instructions. The raw sequences were manually edited 
to check for inconsistency. The nucleotide sequences for the 18S rDNA of wood fungi were obtained by aligning the sequences with the primers. A similarity search for the nucleotide sequence of $18 \mathrm{~S}$ rDNA of the test isolate was conducted online using NCBI and the basic local alignment search tool (BLAST) search program for the nucleotide database, and the sequences were subsequently submitted to GenBank.

\section{Methods}

Chemical compounds analysis

Analysis of the chemical compounds was performed using Chesson Datta methods. Analysis of lignin and cellulose followed the method of Chesson (Datta 1981). A mixture containing $1 \mathrm{~g}$ of dried sample $(a)$ and $150 \mathrm{~mL}$ of distilled water was heated in a water bath at a temperature of $90{ }^{\circ} \mathrm{C}$ to $100{ }^{\circ} \mathrm{C}$ for $1 \mathrm{~h}$. The mixture was filtered, and the residue was washed with hot water $(300 \mathrm{~mL})$. The residue was oven-dried until the weight was constant (b). The residue was mixed with $150 \mathrm{~mL}$ of $1 \mathrm{NH}_{2} \mathrm{SO}_{4}$ and heated in the water bath at 90 ${ }^{\circ} \mathrm{C}$ to $100{ }^{\circ} \mathrm{C}$ for $1 \mathrm{~h}$. The mixture was filtered and washed with $300 \mathrm{~mL}$ of distilled water, and then the residue was dried (c). The dried residue was soaked with $10 \mathrm{~mL}$ of $72 \% \mathrm{H}_{2} \mathrm{SO}_{4}$ at room temperature for $4 \mathrm{~h}$. After that, $150 \mathrm{~mL}$ of $1 \mathrm{~N} \mathrm{H}_{2} \mathrm{SO}_{4}$ was added to the mixture and refluxed in the water bath for $1 \mathrm{~h}$. The solid was washed with $400 \mathrm{~mL}$ of distilled water, heated in the oven at $105^{\circ} \mathrm{C}$, and weighed until a constant weight was achieved $(d)$. Finally, the solid was heated in the kiln at $600{ }^{\circ} \mathrm{C}$ until it became ash and was weighed $(e)$. The percentage of cellulose and lignin was calculated as follows,

$$
\begin{array}{ll}
\text { Cellulose }(\%) & =(c-d) / a \times 100 \\
\text { Lignin }(\%) & =(d-e) / a \times 100
\end{array}
$$

where $a$ is the initial the sample weight $(\mathrm{g}), c$ is the residue weight $(\mathrm{g})$ at the third weighing, $d$ is the residue weight $(\mathrm{g})$ at the fourth weighing, and $e$ is the weight of ash $(\mathrm{g})$

\section{FTIR}

The FTIR spectra of the decayed samples and undecayed controls were measured by direct transmittance using the $\mathrm{KBr}$ pellet technique. Spectra were recorded using a FTIR spectrometer (Nicolet Avatar 360, Minneapolis, MN, USA) equipped with a deuterated triglycine sulfate (DTGS) detector. Wood was removed from the sample surfaces using a double-sided razor and mixed with potassium bromide (for IR spectroscopy) to $0.5 \%$ to $1 \%$ concentration. The sample for FTIR analysis was taken from one sample block whose weight loss reflected the average for that species exposed for that duration. All the spectra were measured at a spectral resolution of $4 \mathrm{~cm}^{-1}$ and 100 scans were taken per sample.

The peak height and area were measured using OMNIC software version 1.2a (Nicolet Instrument Corporation, New York, NY, USA). First, a baseline was constructed by connecting the lowest data points on either side of the peak. A vertical line from the top of the peak to this baseline gave the peak height. The area between the baseline and the top of the peak represented the peak area. The peak height and area values for lignin associated bands were ratioed against the carbohydrate reference peaks to provide the relative changes in the composition of the structural components relative to each other. The assignment of the bands to structural components (as determined by other researchers) is provided in the results. 


\section{RESULTS AND DISCUSSION}

The first isolation resulted in approximately 26 isolates, which were then grouped into 8 groups based on the macroscopic appearance of the fungus. Molecular identification of the fungi produced types of Aspergillus tamarii, Penicillium citrinum, Trichoderma longibrachiatum, Trichoderma reesei, and Fusarium solani (Table 1).

Table 1. Isolates of Wood-destroying Fungi (Wood Coloring or Degradation) that were Successfully Isolated from Samples of Processed Rubber Wood Impregnation Products

\begin{tabular}{|c|c|c|c|c|}
\hline No. & Isolate & $\begin{array}{l}\text { Species (Based } \\
\text { on Molecular } \\
\text { Identification) }\end{array}$ & Phylum & Descriptions \\
\hline 1 & & $\begin{array}{c}\text { Aspergillus } \\
\text { tamarii }\end{array}$ & Ascomycota & $\begin{array}{l}\text { The color of the dark green } \\
\text { colony is like a rather coarse } \\
\text { velvet, spread out in a rather } \\
\text { large circular colony. The rear } \\
\text { appearance is greenish gray. }\end{array}$ \\
\hline 2 & & $\begin{array}{l}\text { Penicillium } \\
\text { citrinum }\end{array}$ & Ascomycota & $\begin{array}{l}\text { The color of the colony is } \\
\text { white but, in the middle, there } \\
\text { is green, spreading to form } \\
\text { one small colony like white } \\
\text { dots. There is green in the } \\
\text { middle, and the back is white } \\
\text { with a yellow dot in the } \\
\text { middle. }\end{array}$ \\
\hline 3 & & $\begin{array}{c}\text { Trichoderma } \\
\text { longibrachiatum }\end{array}$ & Ascomycota & $\begin{array}{l}\text { The color of the surrounding } \\
\text { huja is thick white like flour } \\
\text { droplets, but around it is a } \\
\text { thin white colony with fibers } \\
\text { that form a groove. There is a } \\
\text { change in color on the } \\
\text { medium to dark greenish } \\
\text { yellow. }\end{array}$ \\
\hline 4 & & Fusarium solani & Ascomycota & $\begin{array}{l}\text { Dark white mycelium color is } \\
\text { rather thick like cotton; there } \\
\text { is a tinge of pink / light brown } \\
\text { at the time behind the } \\
\text { brownish white color. }\end{array}$ \\
\hline 5 & & Fusarium solani & Ascomycota & $\begin{array}{l}\text { White colony, thick like } \\
\text { cotton, looks like there is a } \\
\text { circle of growth. There is a } \\
\text { difference in color in the } \\
\text { colonies that are old and } \\
\text { newly growing, white rear } \\
\text { view. }\end{array}$ \\
\hline
\end{tabular}

Rahmawati et al. (2020). "Fungi in impregnated wood," BioResources 15(2), 2839-2849. 2843 


\begin{tabular}{|c|c|c|c|c|}
\hline No. & Isolate & $\begin{array}{l}\text { Species (Based } \\
\text { on Molecular } \\
\text { Identification) }\end{array}$ & Phylum & Descriptions \\
\hline 6 & "u* & Fusarium solani & Ascomycota & $\begin{array}{l}\text { White mycelium, fibrous like } \\
\text { cotton; rather thin and spread } \\
\text { throughout the petri dish but } \\
\text { separated, white rear fibrous } \\
\text { appears white. }\end{array}$ \\
\hline 7 & \% & $\begin{array}{l}\text { Trichoderma } \\
\text { reesei }\end{array}$ & Ascomycota & $\begin{array}{l}\text { Thin white fibrous mycelium } \\
\text { forms a slur from the center } \\
\text { to the outside after an old } \\
\text { green spore arises. }\end{array}$ \\
\hline 8 & & Fusarium solani & Ascomycota & $\begin{array}{l}\text { Mycelium is thick white with } \\
\text { coarse fibers dark white }\end{array}$ \\
\hline
\end{tabular}

The isolated fungi were identified as Aspergillus tamarii, Penicillium citrinum, Trichoderma longibrachiatum, Trichoderma reesei, and Fusarium solani. The result of partial 18S r DNA sequence showed 90 to $99 \%$ homolog with the authors' fungi. Flannigan and Miller (1993) reported that Aspergillus and Penicillium were found as indoor molds in buildings in other parts of world in a considerable percetage. Aspergillus spp., Penicillium spp., and Trichoderma spp. were found to colonize solid wood and wood containing building materials at high moistue content and high humidity conditions that were supportive for spore germination (Pasanen et al. 2000).

Table 2. Chemical Components of Cellulose, Hemicellulose, Lignin, Alcohol Benzene Extractive Content, and Ash Content of Impregnated Wood that are Attacked or Not Attacked by Wood-destroying Fungi

\begin{tabular}{|c|c|c|c|c|c|c|}
\hline No. & Materials & $\begin{array}{c}\text { Alcohol } \\
\text { Benzene } \\
\text { Eztractive } \\
\text { Content } \\
(\%)\end{array}$ & $\begin{array}{c}\text { Cellulose } \\
\text { Content } \\
(\%)\end{array}$ & $\begin{array}{c}\text { Hemicellulose } \\
\text { Content (\%) }\end{array}$ & $\begin{array}{c}\text { Lignin } \\
\text { Content } \\
(\%)\end{array}$ & $\begin{array}{c}\text { Ash } \\
\text { Content } \\
(\%)\end{array}$ \\
\hline 1 & Impregnated rubber wood & 19.67 & 16.56 & 16.07 & 46.97 & 4.26 \\
$(1.24)$ & $(1.43)$ & $(1.33)$ & $(1.05)$ & $(0.72)$ \\
\hline 2 & Rubber veneer & 18.22 & 21.01 & 11.62 & 46.54 & 0.76 \\
& $(1.03)$ & $(1.56)$ & $(1.27)$ & $(1.26)$ & $(0.11)$ \\
\hline 3 & Fungal infected & 17.36 & 14.87 & 7.77 & 58.89 & 3.16 \\
& Impregnated rubber wood & $(1.32)$ & $(1.43)$ & $(1.09)$ & $(1.87)$ & $(0.52)$ \\
\hline
\end{tabular}

Number in parentheses are standard deviation from the sample mean.

The cellulose, hemicellulose, and lignin content in the samples were tested using the Chesson-Datta (1981) method. The Chesson-Datta test serves to express the mass 
percentages of the four compounds found in the sample, namely lignin, cellulose, and hemicellulose.

Table 3. Cold Water, Hot Water, and $\mathrm{NaOH}$ Soluble Extractives

\begin{tabular}{|c|c|c|c|c|}
\hline No. & Materials & $\begin{array}{c}\text { Cold Water Solubility } \\
(\%)\end{array}$ & $\begin{array}{c}\text { Hot Water } \\
\text { Solubility (\%) }\end{array}$ & $\begin{array}{c}\text { NaOH Solubility } \\
(\%)\end{array}$ \\
\hline 1 & Impregnated rubber wood & 14.49 & 16.39 & 32.56 \\
\hline 2 & Rubber wood veneer & 13.73 & 18.27 & 21.18 \\
\hline 3 & $\begin{array}{c}\text { Fungal infected } \\
\text { impregnated rubber wood }\end{array}$ & 12.67 & 15.76 & 27.51 \\
\hline
\end{tabular}

The different chemical properties of the solubility of lignin, cellulose, and hemicellulose were used as a basis for testing the Chesson-Datta method. Where hemicellulose that can dissolve in dilute acid was determined as the first compound measured, then cellulose, which can be decomposed and solubilized in concentrated acid, becomes the second compound measured (Table 3). The last compound measured was lignin. The Chesson-Datta method utilizes the chemical characteristic of lignin being insoluble in concentrated sulfuric acid $\left(\mathrm{H}_{2} \mathrm{SO}_{4}\right)$. The Chesson-Datta method can only measure acid-insoluble lignin and cannot measure acid-soluble lignin (ASL). However, the content of acid-soluble lignin was minimal, i.e. $1 \%$ in conifer wood, while the content in deciduous wood is up to $4 \%$. This acid-soluble lignin can be determined by ultraviolet spectrophotometry measurements at 280, 240, or $205 \mathrm{~nm}$ wavelengths and absorbance compared to the reference lignin sample (Fengel and Wegener 1984). In testing the content of lignin, cellulose, and hemicellulose using the Chesson-Datta method, the ash content (1\% to $1.5 \%$ ) was neglected. Analysis of rubber wood chemical components from the literature with the corresponding TAPPI methods obtained an average value of $3.86 \%$ for extractives that dissolve in cold water. An average value of $4.21 \%$ was found for extractive substances that dissolve in hot water as per TAPPI $207 \mathrm{~cm} 88$ (1992). Extractive substances that were soluble in $1 \% \mathrm{NaOH}(14.82 \%)$ as per TAPPI $212 \mathrm{~cm} 98$ (1992) and extractives that were soluble in ethanol-benzene had an average value of $2.93 \%$ as per TAPPI $204 \mathrm{~cm}$ 97 (1992). The holocellulose content was $75.06 \%$. Cellulose and a-cellulose levels were $43.98 \%$ and $37.71 \%$, respectively, as per TAPPI $203 \mathrm{~cm} 99$ (1999). The lignin content was 26.39\% as per TAPPI 222 om-02 (2002) (Safitri 2003).

Cellulose and hemicellulose content in fungal-infected impregnated rubber wood was slightly lower compared to nonfungal-infected wood (Table 2). Decreasing cellulose and hemicellulose content in fungal-infected impregnated rubber wood was caused by fungi that attacked cellulose and hemicellulose.

The low levels of cellulose in impregnated wood affected by fungal attack was thought to be due to the presence of fungi that are able to degrade cellulose, thereby reducing cellulose content. On the other hand, the apparent high lignin content in impregnated wood that was attack by fungal was attributed to the addition of phenol as part of the impregnation processed.

The FTIR is a useful technique for studying wood decay chemistry because minimal sample preparation is required and small quantities of wood can be analyzed (a few milligrams) when compared to conventional gravimetric techniques, for which several grams are required. 

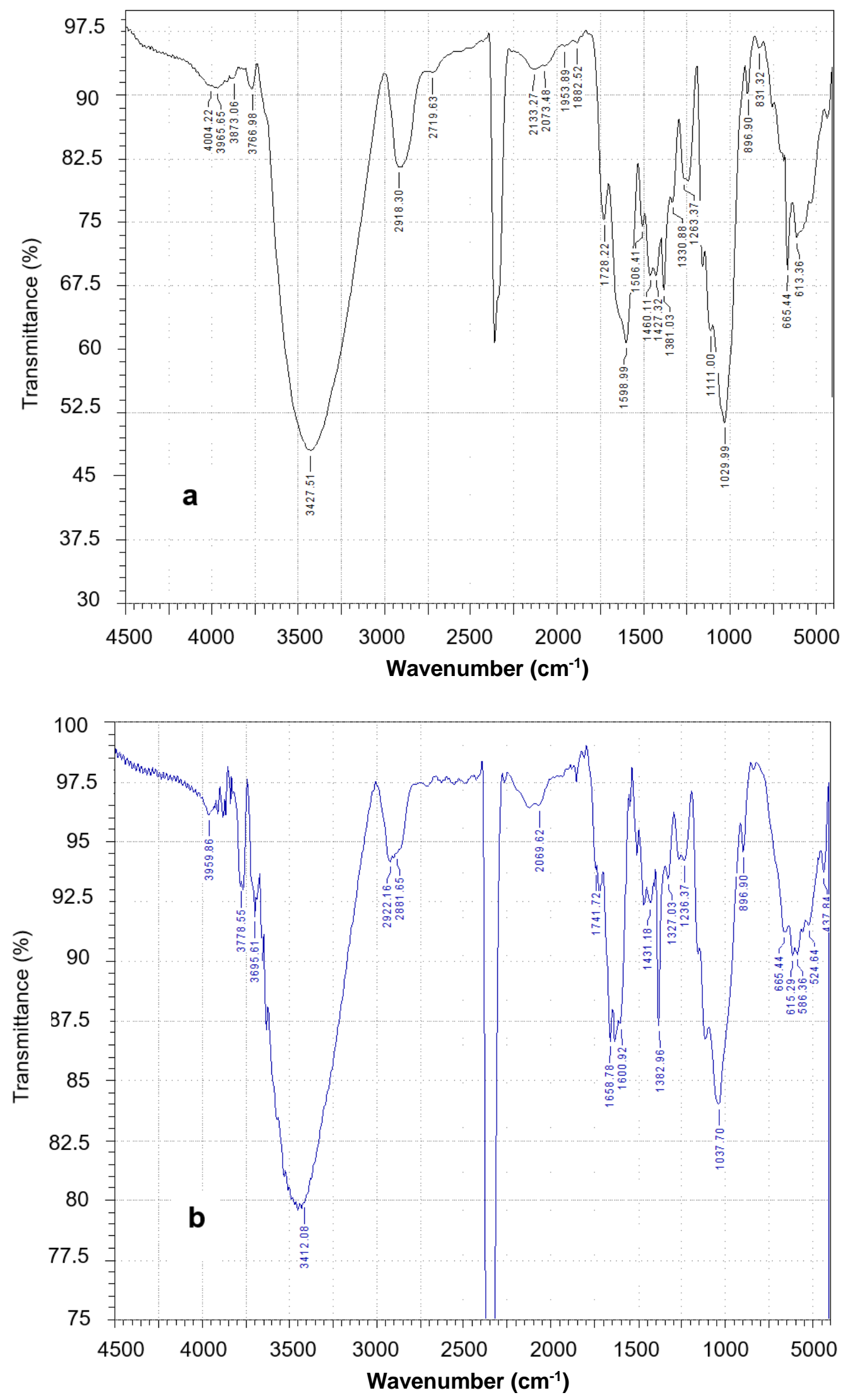

Fig. 2. Chromatograms of impregnated wood that were not affected by fungi (a) and those affected by fungi (b) 
The FTIR method has previously been used to characterize the chemistry of wood (Owen and Thomas 1989; Faix 1992; Pandey 1999) and to determine lignin content in pulp, paper, and wood (Schultz et al. 1985; Berben et al. 1987; Rodrigues et al. 1998). It has also been used for analyzing chemical changes that occur in wood during weathering, decay, and chemical treatments (Moore and Owen 2001; Pandey and Pitman 2003).

The absorption band at 1100 to $1000 \mathrm{~cm}^{-1}$ shows several modes, such as $\mathrm{C}-\mathrm{H}$ deformation or C-O or C-C stretching, which are related to carbohydrates. Strong peaks at $1032 \mathrm{~cm}^{-1}$ and $1039 \mathrm{~cm}^{-1}$ in the spectrum also indicated starch content in the sample. Secondary peaks at 770 to $922 \mathrm{~cm}^{-1}$ correspond to carbohydrate absorption characteristics (Ramamurthy and Kannan 2007).

The $3304 \mathrm{~cm}^{-1}$ absorbance band could also be related to $\mathrm{OH}$ group vibrations. Bands at $1385 \mathrm{~cm}^{-1}$ were associated with $\mathrm{CH}_{3}(\mathrm{CO})$ vibration vibrations. Bands at 1086, 1044, and $877 \mathrm{~cm}^{-1}$ could be caused by carbohydrates. The first two bands were attributed to polysaccharides. Bands at $1086 \mathrm{~cm}^{-1}$ could also be caused by symmetrical stretching (C-OC) 1,8-Cineole (Schulz et al. 2005) bands at $1044 \mathrm{~cm}^{-1}$, which are also associated with $\mathrm{OH}$ group vibrations (Rodriguez et al. 2015). The band at $877 \mathrm{~cm}^{-1}$ could also be caused by vibration stretching $\mathrm{CH}_{2}$ 1,8-Cineole (Schulz et al. 2005) or because of ethanol (Ramamurthy and Kannan 2007).

\section{CONCLUSIONS}

1. Wood-inhabiting fungi that were isolated from impregnated rubber wood were identified as: Aspergillus tamarii, Penicillium citrinum, Trichoderma longibrachiatum, Trichoderma reesei, and Fusarium solani.

2. All isolated fungi were grouped into Ascomycota that were stated as soft rot fungi.

3. These fungi attacked cellulose and hemicellulose. The process was evident due to the decrease in cellulose and hemicellulose content in fungal-infected impregnated rubber wood.

\section{ACKNOWLEDGMENTS}

The authors would like to thank the Directorate of Research and the Community Service Directorate General of Research and Development of the Ministry of Research, Technology, and Higher Education (Research Program PUDT 2019) for supporting the implementation of this research.

\section{REFERENCES CITED}

Berben, S. A., Rademacher, J. P., Sell, L., and Easty, D. B. (1987). "Estimation of lignin in wood pulp by diffuse reflectance Fourier-transform infrared spectrometry," TAPPI Journal 70(11), 129-133.

Datta, R. (1981). "Acitogenic fermentation of lignocellulose - acid yield and conversion of components," Biotechnology and Bioengineering 23(9), 2167-2170. DOI:

10.1002/bit.260230921

Rahmawati et al. (2020). "Fungi in impregnated wood," BioResources 15(2), 2839-2849. 2847 
Faix, O. (1992). "Fourier transform infrared spectroscopy," in: Methods in Lignin Chemistry, S. Y. Lin, and C. W. Dence (eds.), Springer, Berlin, Germany, pp. 83109.

Fengel, D., and Wegener, G. (1984). Wood, Chemistry, Ultrastructure, Reactions, Waster and Grugter, New York, NY, USA.

Flannigan, B., and Miller, J. D. (1993). "Indoor humidity and the building envelope guidelines for evaluation of air borne microbial contamination of buildings," in: Bugs, Mold and Rot II Conference Proceedings, Washington D.C., USA, pp. 43-50.

$\mathrm{Gu}$, J. D. (2003). "Microbiological deterioration and degradation of synthetic polymeric materials: Recent research advances," International Biodeterioration \& Biodegradation 52(2), 69-91. DOI: 10.1016/S0964-8305(02)00177-4

Kalawate, A., and Mehetre, S. (2015). "Isolation and characterization of mold fungi and insects infecting sawmill wood, and their inhibition by gamma radiation," Radiation Physics and Chemistry 117, 191-197. DOI: 10.1016/j.radphyschem.2015.08.016

Moore, A. K., and Owen, N. L. (2001). "Infrared spectroscopic studies of solid wood," Applied Spectroscopy Reviews 36(1), 65-86. DOI: 10.1081/ASR-100103090

Owen, N. L., and Thomas, D. W. (1989). "Infrared studies of hard and soft woods," Applied Spectroscopy 43(3), 451-455. DOI: 10.1366/0003702894202760

Pandey, K. K. (1999). "A study of chemical structure of soft and hardwood and wood polymers by FTIR spectroscopy, " Journal of Applied Polymer Science 71(12), 19691975. DOI:10.1002/(SICI)1097-4628(19990321)71:12<1969::AID-APP6>3.0.CO;2D

Pandey, K. K., and Pitman, A. J. (2003). "FTIR studies of the changes in wood chemistry following decay by brown-rot and white-rot fungi," International Biodeterioration \& Biodeterioration 52(3), 151-160. DOI: 10.1016/S0964-8305(03)00052-0

Pasanen, A. L., Kasanen, J.-P., Sirpa, R., Ikăheimo, M., Rantamäki, J., Kääriainen, H., and Kalliokoski, P. (2000). "Fungal growth and survival in building material under fluctuating moisture and temperature conditions," International Biodeterioration \& Biodegradation 46(2), 117-127. DOI: 10.1016/S0964-8305(00)00093-7

Ramamurthy, N., and Kannan, S. (2007). "Fourier transform infrared spectroscopic analysis of a plant (Calotropis gigantea Linn) from an industrial village, Cuddalore Dt, Tamilnadu, India," Romanian Journal of Biophysics 17(4), 269-276.

Rodríguez-Torres, A., Valladares-Cisneros, M., Gonzalez-Rodríguez, J. (2015). "Use of Salvia officinalis as green corrosion inhibitor for carbon steel in acidic media," International Journal of Electrochemical Science 10, 4053-4067.

Rodrigues, J., Faix, O., and Pereira, H. (1998). "Determination of lignin content of Eucalyptus globulus wood using FTIR spectroscopy," Holzforschung 52(1), 46-50. DOI: $10.1515 / \mathrm{hfsg} .1998 .52 .1 .46$

Safitri, E. S. (2003). Analysis of Chemical Components and Fiber Dimensions of Rubber Wood (Hevea brasiliensis Mueull. Arg.) Clone Results, Bachelor's Thesis, IPBUniversity, Bogor, Indonesia.

Scheffer, T. C. (1973). "Mycrobiological degradation and its causal organisms," in: Wood Deterioration and its Prevention Treatments, D. D. Nicholas (ed.), Syracuse University Press, Syracuse, NY, USA, pp. 31-106.

Schulz, H., Ozkan, G., Baranska, M., Kruger, H., and Ozcan, M. (2005). "Characterization of essential oil plants from Turkey by IR and Raman spectroscopy," Vibrational Spectroscopy, 39(2), 249-256. DOI: 10.1016/j.vibspec.2005.04.009 
Schultz, T. P., Templeton, M. C., and McGinnis, G. D. (1985). "Rapid determination of lignocellulose by diffuse reflectance Fourier transform infrared spectrometry," Analytical Chemistry 57(14), 2867-2869. DOI: 10.1021/ac00291a027

TAPPI T203 mm-99 (1999). “Alpha-, beta- and gamma-cellulose in pulp,” TAPPI Press, Atlanta, GA, USA.

TAPPI T204 om-97 (1992). "Solvent extractives of wood and pulp," TAPPI Press, Atlanta, GA, USA.

TAPPI T207 om-88 (1992). "Official test methods association of the pulp and paper science and technology," TAPPI Press, Atlanta, GA, USA.

TAPPI T212 om-98 (1992). “One percent NaOH solubility of wood and pulp,” TAPPI Press, Atlanta, GA, USA.

TAPPI T222 om-02 (2002). “Acid-insoluble lignin in wood and pulp,” TAPPI Press, Atlanta, GA, USA.

Article submitted: December 10, 2019; Peer review completed: February 22, 2020; Revised version received and accepted: February 28, 2020; Published: March 6, 2020.

DOI: $10.15376 /$ biores. 15.2.2839-2849 